\title{
BSG wt Allele
}

National Cancer Institute

\section{Source}

National Cancer Institute. BSG wt Allele. NCI Thesaurus. Code C95069.

Human BSG wild-type allele is located in the vicinity of 19p13.3 and is approximately $12 \mathrm{~kb}$ in length. This allele, which encodes basig in protein, plays a role in the regulation of metalloprotease gene expression, embryo implantation, spermatogenesis and neural network formation. Aberrant expression of the gene is associated with malignant glioma. 